\title{
Biocompatibility of chemoenzymatically derived dextran-acrylate hydrogels
}

\author{
Lino Ferreira, ${ }^{1}$ Ana Rafael, ${ }^{2}$ Meriem Lamghari, ${ }^{3}$ Mario A. Barbosa, ${ }^{3,4}$ Maria H. Gil, ${ }^{1}$ \\ António M. S. Cabrita, ${ }^{2}$ Jonathan S. Dordick ${ }^{5}$ \\ ${ }^{1}$ Departamento de Engenharia Química, Universidade de Coimbra, Pinhal de Marrocos, 3030-290 Coimbra, Portugal \\ ${ }^{2}$ Instituto de Patologia Experimental, Faculdade de Medicina, Universidade de Coimbra, Portugal \\ ${ }^{3}$ INEB - Instituto de Engenharia Biomédica, Laboratório de Biomateriais, Rua do Campo Alegre, 823, 4150-180 Porto, \\ Portugal \\ ${ }^{4}$ Departamento de Engenharia Metalúrgica e de Materiais, Faculdade de Engenharia, Universidade do Porto, Porto, \\ Portugal \\ ${ }^{5}$ Department of Chemical Engineering, Rensselaer Polytechnic Institute, Troy, New York 12180
}

Received 1 May 2003; revised 26 September 2003; accepted 7 October 2003

\begin{abstract}
The biocompatibility of chemoenzymatically generated dextran-acrylate hydrogels has been evaluated in vitro, using human foreskin fibroblasts, and in vivo, by subcutaneous and intramuscular implantation in Wistar rats for up to 40 days. In vitro tests show that hydrogel extracts only minimally reduced $(<10 \%)$ the mitochondrial metabolic activity of fibroblasts. Direct contact of the hydrogels with cells induced a cellular proliferation inhibition index (CPII) of $50-80 \%$, compared with a control, whereas through indirect contact, the CPII values were $<16 \%$, suggesting that the high CPII values achieved in the direct assay test were likely due to mechanical stress or limitations in oxygen diffusion. Hence, the hydrogels were noncytotoxic. Moreover, cellmaterial interaction studies show that these hydrogels were nonadhesive. Finally, histologic evaluation of tissue response to subcutaneous and intramuscular implants showed acceptable levels of biocompatibility, as characterized by a
\end{abstract}

normal cellular response and the absence of necrosis of the surrounding tissues of the implant. In the first 10 days, the foreign-body reaction in the intramuscular implantation was more severe than in subcutaneous implantation, becoming identical after 30 days. In both cases, dextran hydrogels did not show signs of degradation 6 weeks postimplantation and were surrounded by a thin fibrous capsule and some macrophages and giant cells. This response is typical with a number of nondegradable biocompatible materials. These results indicate that dextran hydrogels are biocompatible, and may have suitable applications as implantable longterm peptide/protein delivery systems or scaffolds for tissue engineering. (C) 2004 Wiley Periodicals, Inc. J Biomed Mater Res 68A: 584-596, 2004

Key words: dextran; hydrogel; cytotoxicity; biocompatibility; biocatalytic polyester

\section{INTRODUCTION}

Recently, we described a novel chemoenzymatic strategy for the preparation of dextran acrylates. ${ }^{1}$ The biocatalytic approach was highly regioselective in the sites of acrylic ester modification of the dextran backbone and resulted in controlled degree of acrylate substitution. Hydrogels were obtained upon free radical polymerization of aqueous solutions of dextranacrylate. These hydrogels may have suitable applica-

Correspondence to: J. S. Dordick; e-mail: dordick@rpi.edu Contract grant sponsor: Fundação para a Ciência e a Tecnologia; contract grant number: Praxis XXI, BD/18456/98

Contract grant sponsor: Biotechnology Research and Development Corporation

(C) 2004 Wiley Periodicals, Inc. tions as implantable protein delivery systems, ${ }^{2,3}$ because of the highly stabilizing effect of polysaccharides on proteins and other biological macromolecules, ${ }^{4,5}$ as protein- and cell-resistant coatings, ${ }^{6-8}$ and as bioactive scaffolds for tissue engineering. ${ }^{9,10}$ In this last case, the cell adhesive properties of the scaffold can be promoted by the immobilization of cell adhesion peptides targeted to specific cell types. ${ }^{11,12} \mathrm{In}$ deed, dextran has multiple binding sites along its chain which can incorporate high concentrations of bioactive molecules. ${ }^{8}$

Irrespective of their specific use and destination, biocompatibility is a prerequisite that makes dextran hydrogels implantable. Nevertheless, few studies have been performed in vitro ${ }^{13}$ and in vivo ${ }^{14}$ on biocompatibility of dextran-based hydrogels. The present study was undertaken to assess the biocompatibility 
of dextran-acrylate hydrogels that were synthesized chemoenzymatically. In vitro biocompatibility tests were performed using human foreskin fibroblasts, which are known to have a major role in cutaneous wound healing. ${ }^{15,16}$ Hydrogel biocompatibility was evaluated according to the extract assay, direct or indirect contact assays, and cell adhesion..$^{3,17,18}$ In vivo biocompatibility and degradability were determined after subcutaneous and intramuscular implantation into Wistar rats for up to 40 days. These results indicate that dextran hydrogels are biocompatible and the inflammatory and healing responses of rat tissues were influenced by the initial water content and the degree of substitution (DS) of the hydrogels.

\section{EXPERIMENTAL PROTOCOL}

\section{Materials}

Dextran (from Leuconostoc mesenteroides, dexT70, $M_{\mathrm{n}}=$ $39,940, M_{\mathrm{w}}=70,000$, according to the manufacturer's specification) was obtained from Fluka Chemie AG (Buchs, Switzerland). Dimethylsulfoxide, $N, N, N^{\prime}, N^{\prime}$-tetramethylenediamine (TEMED), and ammonium persulfate (APS) were purchased from Aldrich (Milwauke, WI). Dextran acrylates (dexT70-VA) with different DS were synthesized as described previously. ${ }^{1}$ The products were characterized by ${ }^{1} \mathrm{H}$ NMR to assess DS. Dulbecco's modified Eagle medium (DMEM) with glutamax-I (Gibco, UK) was supplemented with $10 \%$ fetal bovine serum (Gibco), $1 \%$ of fungizone (250 $\mu \mathrm{g} / \mathrm{mL}$ amphotericin B; Gibco) and $0.5 \%$ gentamicin (10 $\mathrm{mg} / \mathrm{mL}$; Gibco). This medium is further referred to as DMEM complete medium. MTT (3-[4,5-dimethylthiazol-2yl]-2,5-diphenyl-tetrazolium bromide) was obtained from Sigma (St. Louis, MO). Transwell plates (six wells) were purchased from Corning (Corning, NY) and were formed by a suspended tissue culture-treated polycarbonate membrane (24-mm diameter; $8.0-\mu \mathrm{m}$ pore size) and a polystyrene plate. All other chemicals and solvents used in this work were of the highest purity commercially available.

\section{Gel preparation}

Dext70-VA hydrogels were obtained by free radical polymerization of aqueous solutions of dexT70-VA as a function of DS and monomer concentration. Dext70-VA (80 or 200 $\mathrm{mg}$ ) was dissolved in $0.9 \mathrm{~mL}$ of $0.2 \mathrm{M}$ phosphate buffer, $\mathrm{pH}$ 8.0, and bubbled with nitrogen for $2 \mathrm{~min}$. The polymerization reactions, performed in a cell culture plate (diameter $\approx 1.8 \mathrm{~cm}$ ), were initiated by adding $50 \mu \mathrm{L}$ of APS $(80 \mathrm{mg} / \mathrm{mL}$ in $0.2 \mathrm{M}$ phosphate buffer, $\mathrm{pH} 8.0$ ) and $50 \mu \mathrm{L}$ of TEMED solution $[13.6 \%$ (v/v) in water; $\mathrm{pH}$ adjusted to 8.0 with $12 \mathrm{~N}$ $\mathrm{HCl}$, and allowed to proceed for $24 \mathrm{~h}$ at $25^{\circ} \mathrm{C}$. The hydrogels synthesized contained an initial water content of $92 \%(w / w)$ and $80 \%(\mathrm{w} / \mathrm{w})$, when $80 \mathrm{mg}$ and $200 \mathrm{mg}$ of dexT70-VA macromonomer were used, respectively, and maintaining constant the other components.

\section{Swelling ratio determination}

After removal of the hydrogels from the plate, they were immersed in about $50 \mathrm{~mL}$ of $0.01 \mathrm{M}$ citrate-phosphate buffer, $\mathrm{pH} 7.0$, changing the buffer daily, at $25^{\circ} \mathrm{C}$ (in some cases, after removing the hydrogels, they were dried and weighed to determine their initial dry weight). At regular intervals, the swollen gels were removed, blotted with filter paper to remove surface water, weighed, and returned to the same container until weight stabilization $\left(W_{\mathrm{s}}\right)$ was observed (normally up to 7 days). In some cases, the hydrogel disks were steam-sterilized for $20 \mathrm{~min}$ at $120^{\circ} \mathrm{C}$ followed by equilibration of the hydrogels for $24 \mathrm{~h}$ at $25^{\circ} \mathrm{C}$. The hydrogels were then dried at room temperature, under vacuum, in the presence of phosphorous pentoxide (until constant weight was achieved), and weighed to determine the dry weight, $W_{\mathrm{d}}$. The swelling ratio at equilibrium (SRE) was calculated according to Equation (1):

$$
S R E=\frac{W_{\mathrm{s}}-W_{\mathrm{d}}}{W_{\mathrm{d}}}
$$

The gel fraction of hydrogels was calculated from the ratio of the dry weight of hydrogel after swelling and the initial dry weight immediately after the polymerization reaction. The sol fraction was calculated as 1 - gel fraction.

\section{In vitro biocompatibility tests}

\section{Cell culture}

Primary human skin fibroblasts were grown in DMEM complete medium, at $37^{\circ} \mathrm{C}$, in a fully humidified air containing $5 \% \mathrm{CO}_{2}$ (IR auto Flow). The cells were fed every 2-3 days. When cells reached confluence, the culture medium was discarded and the cells were washed with $5 \mathrm{~mL}$ of 10 $\mathrm{mM}$ phosphate-buffered saline (PBS) $\mathrm{pH} 7.4$ (Gibco). The cells were then detached with $2 \mathrm{~mL}$ of $0.05 \%(\mathrm{w} / \mathrm{v})$ trypsin [1:250, from porcine pancreas (Sigma)] solution [PBS supplemented with 0.1 and $0.25 \%$ of $\alpha-\mathrm{D}(+)$ glucose and ethylenediaminetetracetic acid, respectively] for $5 \mathrm{~min}$ at $37^{\circ} \mathrm{C}$, and $3 \mathrm{~mL}$ of DMEM complete medium was added to inactivate the trypsin after cell detachment. The cells were centrifuged (10 min, $2500 \mathrm{rpm}$ ) and resuspended in culture medium before use. Cultures between the third and seventh passages were used in the entire work (ca. 20 can be used without loss of fibroblast-like phenotype and cell proliferation rate).

\section{Solutions of dextran, dexT70-VA, TEMED, and APS}

All solutions were prepared on the day of application. Solutions of 10, 20, 50, and $100 \mathrm{mg}$ of dextran or dexT70-VA (DS $7.2 \%$ or DS $12.1 \%$ ) per milliliter of DMEM complete and solutions of $2.5,10,30$, and $50 \mu \mathrm{L}$ of APS or TEMED per 


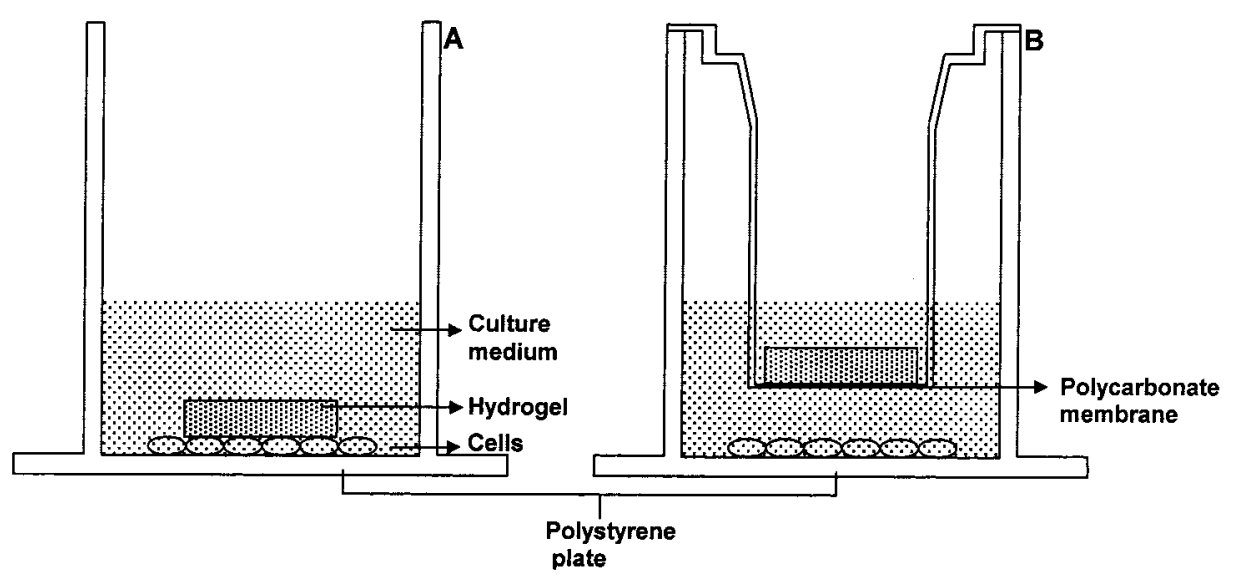

Figure 1. Schematic representation of the direct (A) and indirect (transwell experiment) (B) contact assays. Both assays use growing cells instead of subconfluent cells as in the extraction assay.

milliliter of DMEM complete medium were sterilized through a $0.22-\mu \mathrm{m}$ filter (Schleicher \& Schuell, Dassel, Germany), with the exception of $100 \mathrm{mg} / \mathrm{mL}$ dexT70-VA solutions for which a $0.45-\mu \mathrm{m}$ filter (Schleicher \& Schuell) was used because of the higher viscosity.

\section{Extraction assay}

The extraction assay was performed with two sets of hydrogels. In one set, the hydrogels obtained after polymerization of dextran-acrylate were extracted for 2 days in 10 $\mathrm{mM}$ citrate-phosphate buffer $\mathrm{pH} 7.0(3 \times 40 \mathrm{~mL})$, at $25^{\circ} \mathrm{C}$, and afterward autoclaved. In the second set, the hydrogels obtained after the polymerization reaction were immersed in $10 \mathrm{~mL}$ of $10 \mathrm{mM}$ citrate-phosphate $\mathrm{pH} 7.0$ and immediately autoclaved. Extracts were obtained by immersing autoclaved hydrogels in DMEM (without phenol red) culture medium supplemented with $1 \%$ fungizone and $0.5 \%$ gentamicin, at $37^{\circ} \mathrm{C}$, for 5 days with agitation $(120 \mathrm{rpm})$. The ratio between the surface area of the material and the volume of extraction medium was $3 \mathrm{~cm}^{2} / \mathrm{mL}$. After incubation, the medium containing the extract was collected, filtered $(0.22$ $\mu \mathrm{m}$; to eliminate the possible presence of solid particles of the material), and supplemented with $10 \%$ serum. Human skin fibroblasts were plated in 96-well plates (TPP, Switzerland) and grown to subconfluency. The culture medium was removed and replaced with the extract media for $24 \mathrm{~h}$ at $37^{\circ} \mathrm{C}$. Phenol $(64 \mathrm{~g} / \mathrm{L}, \mathrm{BDH})$, which is considered cytotoxic, ${ }^{17}$ was used as a positive control. Culture medium without extracts, incubated as described above, was used as a negative control. After incubation, the extracts were discarded and the mitochondrial metabolic activity of the cells was measured with the MTT assay. To test the cytotoxicity of dextran, dexT70-VA, TEMED, and APS solutions (see above), $100 \mu \mathrm{L}$ of each test solution was added to each well plated with subconfluent cells.

\section{CPII assay: Direct contact assay}

The CPII assay was performed according to De Groot et al., ${ }^{13}$ which allows cytotoxicity evaluation on growing cells.
To evaluate the CPII for solutions of dextran, dexT70-VA, TEMED, and APS, $100 \mu \mathrm{L}$ of a fibroblast suspension containing $1.55 \times 10^{4}$ cells $/ \mathrm{mL}$ was plated into each well of a 96-well plate. Because each well has a surface area of 0.31 $\mathrm{cm}^{2}$, the final seeding density was about $5 \times 10^{3}$ cells $/ \mathrm{cm}^{2}$. After $4 \mathrm{~h}$ (the cells were adherent to the well bottom), the culture medium was discarded and $200 \mu \mathrm{L}$ of each test solution was added to each well. For the control culture, the medium was refreshed. Seventy-two hours after the addition of test solutions, the extracts were discarded and the cell layer was washed with PBS to remove remaining materials and loose cells. The metabolic activity of the cells was then measured with the MTT test (see below). The CPII was calculated using Equation (2):

$$
\mathrm{CPII}=100-\left(\frac{\mathrm{OD}_{540} \text { of test culture }}{\mathrm{OD}_{540} \text { of control culture }} \times 100\right)
$$

To evaluate the CPII for dexT70-VA hydrogels (extracted for 3 days in water at $25^{\circ} \mathrm{C}$ and then sterilized by autoclave), $3 \mathrm{~mL}$ of a fibroblast suspension containing $1.5 \times 10^{4}$ cells $/ \mathrm{mL}$ was plated into each well of a six-well plate, to yield a final density of $5 \times 10^{3}$ cells $/ \mathrm{cm}^{2}$. After $4 \mathrm{~h}$, the culture medium was refreshed $(3 \mathrm{~mL})$ and the hydrogels were added to the wells, in direct contact with cells [Fig. 1(A)]. For the control culture, the culture medium was refreshed. After $72 \mathrm{~h}$ of incubation, the metabolic activity of the cells was assessed as previously described above and the CPII calculated according to Equation (2).

\section{CPII assay: Indirect contact assay}

The CPII of hydrogel samples was also evaluated using transwell plates, containing a final density of $5 \times 10^{3}$ cells/ $\mathrm{cm}^{2}$ [Fig. 1(B)]. In this case, after polymerization (without any extraction), the hydrogels were sterilized by autoclaving, washed twice with DMEM complete medium, and seeded into the wells in indirect contact with the cells (total of $4 \mathrm{~mL}$ of culture medium). After $72 \mathrm{~h}$ of incubation, the metabolic activity of the cells was determined as described above for the direct contact assay, and the CPII calculated according to Equation (2). 
Cell adhesion assay

Filtered $(0.45 \mu \mathrm{m})$ dexT70-VA solutions $(450 \mu \mathrm{L})$ were placed into each well of a 24-well plate and polymerized by addition of filtered APS $(25 \mu \mathrm{L})$ and TEMED $(25 \mu \mathrm{L})$ solutions, in sterile conditions. After $24 \mathrm{~h}$ of polymerization, the hydrogels covering the bottom of the wells were washed with DMEM complete medium $(3 \times 450 \mu \mathrm{L})$ and $1.0 \times 10^{4}$ cells $/ \mathrm{cm}^{2}$ were seeded onto the surface. After $24 \mathrm{~h}$ of incubation, the hydrogels were washed with PBS $(2 \times 450 \mathrm{~mL})$ and the cells trypsinized and counted using a cell counting chamber (Nfubauer, Germany).

\section{Mitochondrial metabolic activity assay}

For 96-well plates, the cell layers were rinsed with PBS $(110 \mu \mathrm{L})$ and $110 \mu \mathrm{L}$ of MTT $(0.45 \mathrm{mg} / \mathrm{mL}$ in DMEM complete medium without phenol red) was added to each well. For six-well plates, after PBS washing $(1 \mathrm{~mL}), 2.5 \mathrm{~mL}$ of MTT solution was added. After $3 \mathrm{~h}$ of incubation at $37^{\circ} \mathrm{C}$, the MTT solution was removed and the insoluble formazan crystals formed in the bottom of the wells were dissolved in $100 \mu \mathrm{L}$ or $1 \mathrm{~mL}$ of dimethylsulfoxide, for 96- and 6-well plates, respectively. The absorbance was measured at $540 \mathrm{~nm}$ using a plate reader (STL Spectra III, Austria).

\section{In vivo biocompatibility studies}

\section{Animals}

Male Wistar rats (8-10 weeks old) were obtained from the Faculty of Medicine of Coimbra University and used for all studies. Rats were given standard feed and water ad libitum and were on a 12-h light/dark cycle. European community guidelines (no. 86/609/CE; corresponding to decree no. $1005 / 92$ of Portuguese legislation) for the care and use of laboratory animals were observed.

\section{Implantation studies}

Aseptic techniques were used for all surgical procedures. Animals were anesthetized with $\mathrm{Ketalarz}^{\circledR}$ (50 mg kg ${ }^{-1}$; Parke-Davis) and an area of the back and front was shaved and washed with Betadine ${ }^{\circledR}$. In the front, two incisions along the spine (ca. $1 \mathrm{~cm}$ in length) were made and two subcutaneous pockets were created. The gels $(3 \times 2 \mathrm{~mm}, 3-\mathrm{mm}$ thickness) were placed into the pocket away from the incision (ca. $0.5 \mathrm{~cm}$ ) and the skin was closed with Mersilk ${ }^{\circledR}$ nonabsorbable suture ( $\varnothing_{\mathrm{s}}$; Ethicon). In the back, two incisions along the spine (ca. $1 \mathrm{~cm}$ in length) were made and a further incision was performed in each case in the skeletal muscle (Gluteus superficialis) to implant the gel. The muscle incision was closed with sterile polypropylene suture $(6 \varnothing \mathrm{s}$; Ethicon) and the skin incision closed with Mersilk ${ }^{\circledR}$ suture (see above). The two areas were washed with Betadine ${ }^{\circledR}$ dermic solution and the rats kept warm with a heating pad for $1 \mathrm{~h}$ after the surgical procedure and finally transferred to a cage. Three rats were used for each time point. As controls, subcutaneous and intramuscular pockets were made without implants.

\section{Histological examination}

The rats were euthanized and the implants with surrounding tissue were carefully dissected and fixed in $4 \%$ $(\mathrm{v} / \mathrm{v})$ neutral buffered formalin, for at least 3 days. The blocks were sliced perpendicular or cross-sectional to the implanted hydrogels. The implant and adjacent tissue were oriented and placed in processing cassettes, taken through a graded ethanol series (Shandon Citadel 1000) and embebbed in paraffin. The samples were then sectioned using a microtome (Shandon Retraction AS 325), and finally deparaffinized and stained either with hematoxylin/eosin, periodic acid-schiff (PAS), or Masson's trichrome. ${ }^{19}$ Multiple photographs were taken of each hydrogel and the surrounding tissues using a Nikon microscope (Eclipse E 600) with a Nikon camera (FOX-35). The tissue response was rated by two persons. Capsule thickness was measured on nine fields per section, obtained from different blocks.

\section{Statistical analysis}

One-way analysis of variance with Bonferroni post test was performed for statistical tests by using GraphPad Prism 3.0 (San Diego, CA) software package. A $p$ value of $<0.01$ was considered to be statistically significant.

\section{RESULTS}

Several DexT70-VA hydrogels were prepared chemoenzymatically as described previously. ${ }^{1}$ SRE and gel fraction were dependent on both the initial water content of the gel and the DS, as well as further treatment by autoclaving. As shown in Table I, the gel fractions of nonsterilized dexT70-VA hydrogels were between 59 and $83 \%$, which indicates that incubation of these networks in water at $37^{\circ} \mathrm{C}$ leads to considerable release of polymeric components. Subsequent autoclaving did not alter significantly the gel fraction, thus showing that this step did not hydrolyze the hydrogel network. SRE values ranged from 3.7 to 31 for nonsterilized hydrogels (Table I). In addition, the treatment by autoclaving slightly increased the SRE, particularly in hydrogels with low initial water content $(80 \%)$.

\section{In vitro biocompatibility}

\section{Cytotoxicity assays}

To identify whether components of the hydrogel synthesis procedure were cytotoxic, subconfluent hu- 
TABLE I

Characteristics of dexT70-VA Hydrogels

\begin{tabular}{|c|c|c|c|c|}
\hline \multirow{2}{*}{$\begin{array}{c}\text { DexT70-VA } \\
\text { Hydrogel }\end{array}$} & \multicolumn{2}{|c|}{$\begin{array}{c}\text { Gel Fraction }{ }^{\mathrm{a}} \\
(\%)\end{array}$} & \multicolumn{2}{|c|}{$\operatorname{SRE}^{\mathrm{d}}$} \\
\hline & $\mathrm{BS}^{\mathrm{b}}$ & $\mathrm{AS}^{\mathrm{c}}$ & $\mathrm{BS}^{\mathrm{b}}$ & $\mathrm{AS}^{\mathrm{c}}$ \\
\hline $92 \%$, DS 7.2\% & 59.0 & 55.7 & 31.5 & 36.6 \\
\hline $92 \%$, DS $12.1 \%$ & 74.5 & 74.3 & 14.4 & 14.4 \\
\hline $92 \%$, DS $22.4 \%$ & - & - & 11.0 & 11.5 \\
\hline $92 \%$, DS 31.5\% & - & 77.8 & 9.78 & 10.6 \\
\hline $80 \%$, DS $7.2 \%$ & 80.2 & 78.5 & 7.32 & 10.2 \\
\hline $80 \%$, DS $12.1 \%$ & 83.0 & 84.7 & 4.39 & 5.86 \\
\hline $80 \%$, DS $22.4 \%$ & - & - & 3.99 & 5.32 \\
\hline $80 \%$, DS $31.5 \%$ & - & 81.1 & 3.72 & 4.80 \\
\hline
\end{tabular}

${ }^{\text {a }}$ The hydrogels were extracted in water for 5 days (in some cases further sterilized by autoclave), dried, and weighed. The final dry weights were compared with the sample initial dry weight (immediately after the polymerization reaction) to calculate the gel fraction. Average of two independent measurements.

${ }^{b}$ Before sterilization by autoclave.

${ }^{\mathrm{c}}$ After sterilization by autoclave.

${ }^{\mathrm{d}}$ Swelling ratio at equilibrium. Average of two independent measurements.

man skin fibroblasts were exposed to extracts of hydrogels prepared with different DS values and initial water contents. Cellular viability was quantified using the standard MTT assay. ${ }^{20}$ Two sets of hydrogels were used for the extraction assay. In one set, the hydrogels were extracted in $10 \mathrm{mM}$ citrate-phosphate buffer, $\mathrm{pH}$ 7.0, for 2 days and then autoclaved. In the second set, the hydrogels obtained after polymerization were immediately autoclaved. Afterward, both sets of hydrogels were extracted in cell culture medium for 5 days at $37^{\circ} \mathrm{C}$ and the extracts incubated with fibroblast cultures for $24 \mathrm{~h}$. The results of the MTT assays [Fig. 2(A)] show that the extracts of all hydrogels induce $<20 \%$ change in the mitochondrial metabolic activity of fibroblasts (MMAF), as compared with the control. Nonextracted hydrogels with an initial water content of $92 \%$ exerted a statistically significant increase in MMAF (10-20\%); however, no effect was observed in extracted hydrogels. In some cases, extracted or nonextracted hydrogels with an initial water content of $80 \%$ induced an approximately $10 \%$ reduction in MMAF.

Dextran hydrogels can release leachable products during the extraction assay (Table I) and, therefore, the cytotoxicity of individual hydrogel components was evaluated. Solutions of dextran, dexT70-VA monomers with different DS values (7.2 and $12.1 \%$; dexT70-VA DS 31.5\% was not evaluated because of restrictions in the amount), APS, and TEMED were incubated with fibroblast cultures for $24 \mathrm{~h}$ under the same conditions as described for dexT70-VA hydrogel extracts, and the cellular viability assessed by the MTT assay [Fig. 2(B)]. Dextran solution at a concentration of $10 \mathrm{mg} / \mathrm{mL}$ induced a statistically significant $(p<0.001)$ increase in the MMAF (ca. $20 \%$ ), although this effect was not significant in the concentration range of $20-100 \mathrm{mg} / \mathrm{mL}$. In contrast, dexT70-VA monomers with different DS values slightly reduced $(10-20 \%)$ the MMAF at $50 \mathrm{mg} / \mathrm{mL}$; however, did so extensively $(>80 \%)$ at concentrations of $100 \mathrm{mg} / \mathrm{mL}$. Finally, TEMED and APS exerted a significant $(p<0.001)$ decrease in MMAF for concentrations $>2.5 \mu \mathrm{L} / \mathrm{mL}$.

Cytotoxicity studies were extended to evaluate the CPII. To that end, the toxicity of either hydrogels or single components of the hydrogels was evaluated in actively growing cell culture for $72 \mathrm{~h}$. As shown in Figure 3(A), the CPII values of dextran solutions in the
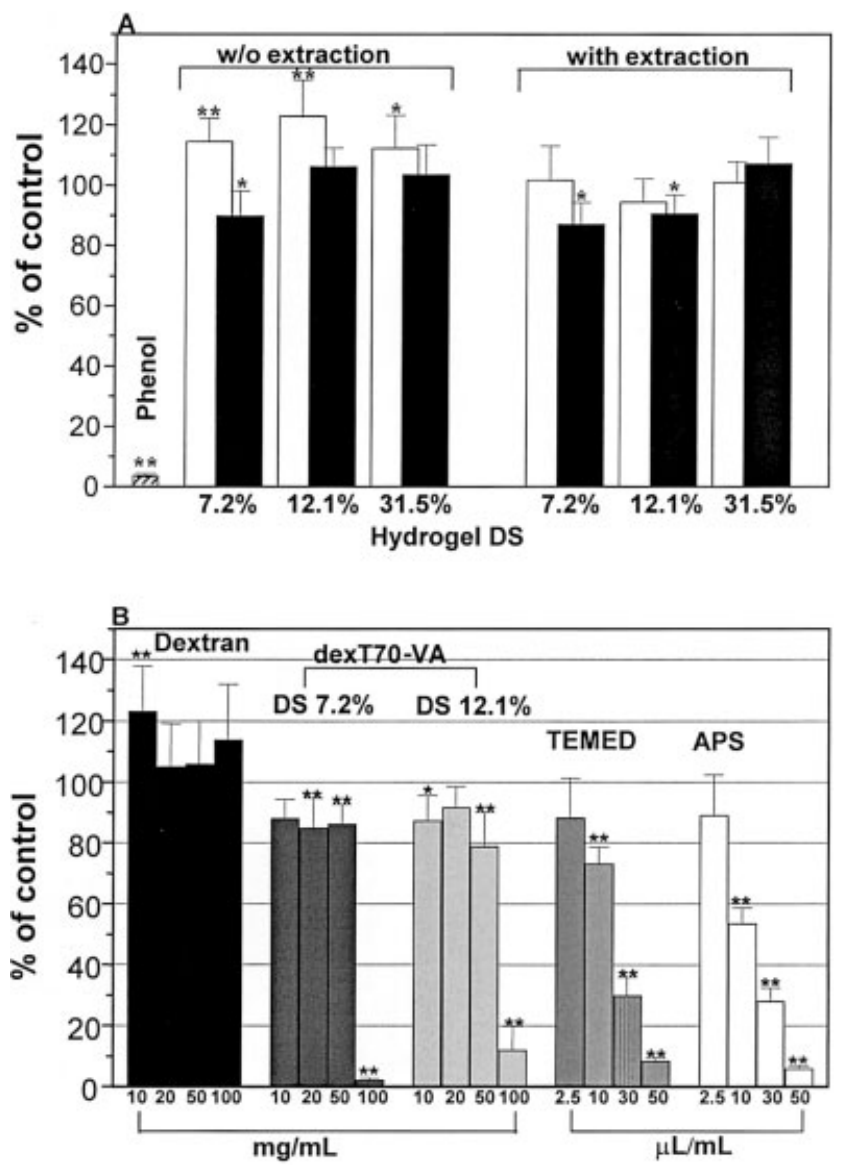

Figure 2. (A) The mitochondrial metabolic activity (mean $\pm \mathrm{SD}, n=6$ ) of human skin fibroblasts cultured for $24 \mathrm{~h}$ with extracts from $92 \%$ (white bars) and $80 \%$ (black bars) dexT70-VA hydrogels with different DS values, as determined by the MTT assay (reported as percentage of the negative controls). Hydrogels denoted as extraction indicates that the hydrogels were immersed in citrate-phosphate buffer, $10 \mathrm{mM} \mathrm{pH} \mathrm{7.0,} \mathrm{for} 2$ days before autoclaving. w/o, without. (B) The mitochondrial metabolic activity (mean \pm $\mathrm{SD}, n=6$ ) of human skin fibroblasts cultured with dextran, dexT70-VA with different DS values, TEMED, and APS, for $24 \mathrm{~h}$, as determined by the MTT assay (reported as percentage of the negative controls). ${ }^{*} p<0.01$ and ${ }^{* *} p<0.001$ in comparison with negative controls. 

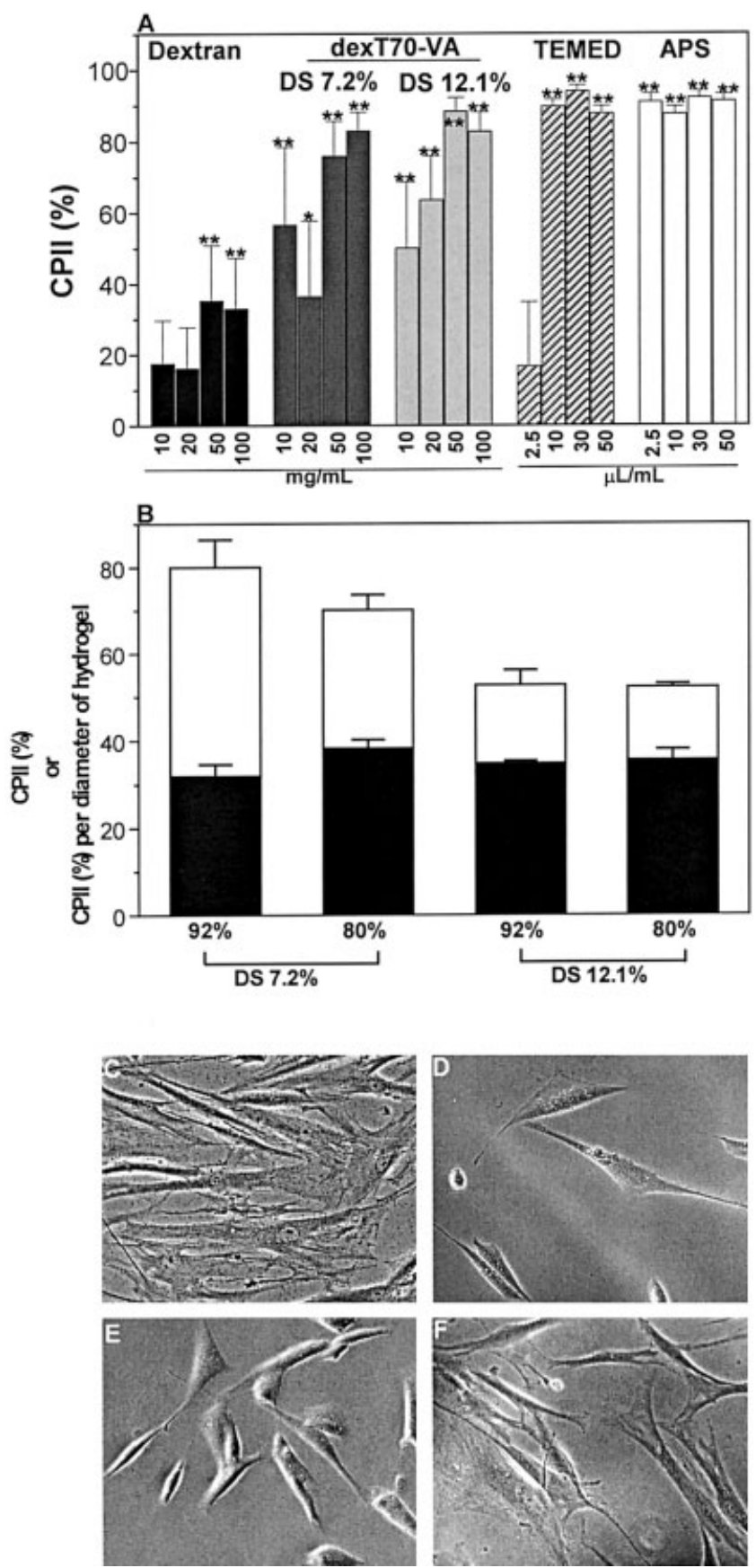

Figure 3. (A) The cell (human skin fibroblasts) proliferation inhibition index (CPII) (mean \pm SD, $n=6$ ) after $72 \mathrm{~h}$ for dextran, dexT70-VA with different DS values, TEMED, and APS solutions, as determined by the MTT assay. (B) The CPII (white bars, mean $\pm \mathrm{SD}, n=2$ ) or CPII normalized by diameter of hydrogel (black bars) after $72 \mathrm{~h}$, for dexT70-VA hydrogels with different DS values in direct contact with cells, as determined by the MTT assay. (C-F) Micrographs from phase-contrast inverted light microscopy of human skin fibroblasts cultured for $72 \mathrm{~h}$, underneath dexT70-VA hydrogels (D-F) or in the absence of hydrogel (C). In (D), $92 \%$ DS 7.2\%; (E), 80\% DS 7.2\%; and (F), 80\% DS $12.1 \%$. Original magnification, 200×. ${ }^{*} p<0.01$ and ${ }^{* *} p<0.001$ in comparison with negative controls. concentration range of $10-20 \mathrm{mg} / \mathrm{mL}$ were about $18 \%$, not statistically different from the control; however, at higher concentrations, the CPII significantly $(p<$ 0.001 ) increased to about $35 \%$. CPII values of dexT70-VA monomers with DS 7.2 and $12.1 \%$ were between 36 and $64 \%$ for a concentration range of $10-20 \mathrm{mg} / \mathrm{mL}$, and this was increased to about $80 \%$ at higher concentrations. Finally, APS caused a significant reduction in the MMAF for all concentrations (CPII values of ca. 90\%), albeit with TEMED the same phenomenon was observed above $2.5 \mu \mathrm{L} / \mathrm{mL}$.

The cytotoxicity of dexT70-VA hydrogels was also assessed by the CPII test using a direct contact method [Fig. 3(B)]. Specifically, the hydrogels were seeded into the cellular layer of a six-well plate [Fig. 1(A)]. DexT70-VA hydrogels with low DS (7.2\%) yielded higher values of CPII (70-80\%) than high DS hydrogels (ca. $52 \%$ ). Because the hydrogels have different diameters after swelling, the CPII was normalized per diameter of the hydrogel. In this case, the CPII values were identical which indicates that hydrogel size had an important role.

Light microscopy was also undertaken to characterize the morphology of the cells under and in the proximity of the hydrogels [Fig. 3(C-F)]. Cells in the proximity of the hydrogels appeared to have normal morphology, as compared with the control [Fig. $3(\mathrm{C})]$, and were well spread on the polystyrene matrix (data not shown). However, for dextran hydrogels with low DS (7.2\%), independent of the water content, the cells underneath the hydrogels were less elongated and less well spread [Fig. 3(D,E)]. In contrast, the cells under the $80 \%$ dexT70-VA DS $12.1 \%$ hydrogel [Fig. 3(F)] did not present a significantly different morphology, as compared with the control cells albeit they were lower in number.

To assess whether the high values of CPII obtained by the direct contact assay were truly due to hydrogel toxicity or to other side effects, an indirect contact assay [transwell experiment, Fig. 1(B)] was performed. As shown in Figure 4, the CPII decreased to values $<16 \%$ and were not statistically different from the control.

\section{Cell-adhesion assay}

Cell adhesion onto hydrogels was evaluated and expressed as a percentage of control adhesion on tissue culture polystyrene (TCPS) [Fig. 5(A)]. Fibroblast adhesion was reduced in all hydrogels tested with different DS values and initial water contents $(<28 \%)$. Because dextran hydrogels were transparent, cell morphology was evaluated by phase-contrast inverted light microscopy [Fig. 5(B,C)]. After $24 \mathrm{~h}$ of cell incubation in the presence of the hydrogels, the relatively few cells attached were rounded and formed clusters 


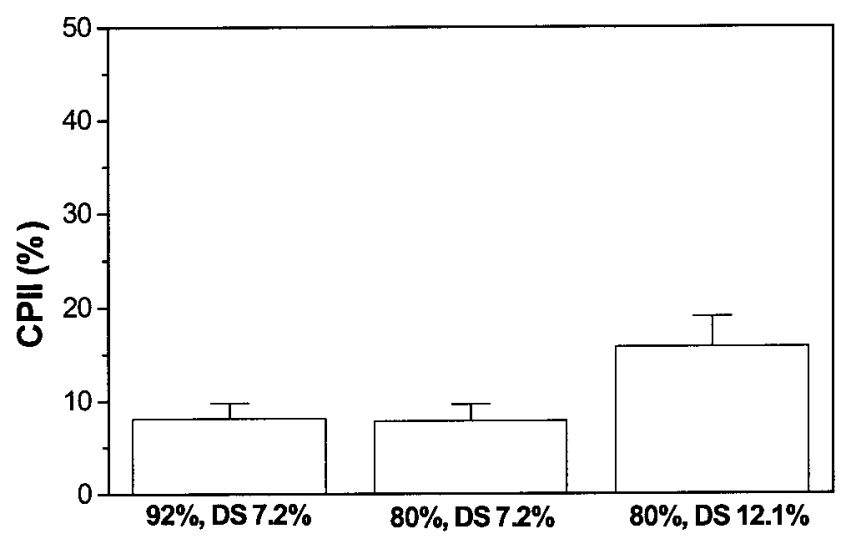

Figure 4. The cell (human skin fibroblasts) proliferation inhibition index (CPII) (mean $\pm \mathrm{SD}, n=3$ ) after $72 \mathrm{~h}$ for dexT70-VA hydrogels with different DS values in indirect contact with cells (transwell experiment, see text for further details), as determined by an MTT assay.

without filopodia to anchor the cells to the hydrogels, as observed by scanning electron microscopy (data not shown).

\section{In vivo biocompatibility}

DexT70-VA hydrogel samples were subcutaneous and intramuscularly implanted in rats and the intensity of the inflammatory response to the foreign implants was monitored by histology at varying implantation times. Table II provides an overview of the nature and extent of the observed tissue reaction after implantation of hydrogels with different initial water contents and DS values.

\section{Subcutaneous implantation}

At day 2, 80\% dexT70-VA DS 7.2\% was mainly surrounded by fibroblasts. Some lymphocytes, but no granulocytes, were observed [Fig. 6(A,B)]. Fibrin and exudate were also identified in the proximity of the hydrogel. In contrast, the other dextran hydrogels did show the presence of granulocytes to different extents, which were attached to the interface of the hydrogel/tissue. Typically, dextran hydrogels with high initial water content attracted higher numbers of granulocytes, and also yielded greater vascularization.

At day 5 after implantation, the cell layer surrounding the $80 \%$ dexT70-VA hydrogel DS 7.2\% consisted primarily of fibroblasts but also of smaller fractions of granulocytes and lymphocytes. The other dextran hydrogels did not present granulocytes. In $80 \%$
dexT70-VA DS 22.4\% hydrogel, some foreign-body giant cells (FBGC) were already observed.

At day 10, the start of fibrous capsule was observed in the $80 \%$ dexT70-VA DS $7.2 \%$ hydrogel, and macrophages and fibroblasts were found between this capsule and the hydrogel [Fig. 6(C,D)]. No granulocytes, exudate, and fibrin were found at this stage. Lymphocytes were observed only occasionally and the number of blood vessels remained approximately constant as compared with the previous postimplantation time. Similar tissue reactions were observed for the other dextran hydrogels. For $92 \%$ dexT70-VA DS 7.2\% hydrogel, the fragmentation was higher than that observed for the other hydrogels (in general restricted to the outer limits), likely because of mechanical stress on this relatively soft hydrogel. Finally, giant cells were observed for hydrogels with lower initial water contents $(80 \%)$, whereas they were absent in hydrogels with higher initial water contents (92\% dexT70-VA DS $7.2 \%)$.

At day $30,80 \%$ dexT70-VA DS $7.2 \%$ hydrogel was surrounded by a thin layer of macrophages and fibroblasts and a fibrous capsule had formed around this layer (thickness of ca. $54.50 \pm 23.28 \mu \mathrm{m}, n=2$ ) [Fig. $6(\mathrm{E}, \mathrm{F})]$. The same profile was observed in the other hydrogels, and the interface of the hydrogel/tissue was less vascularized than at day 10. Finally, in the

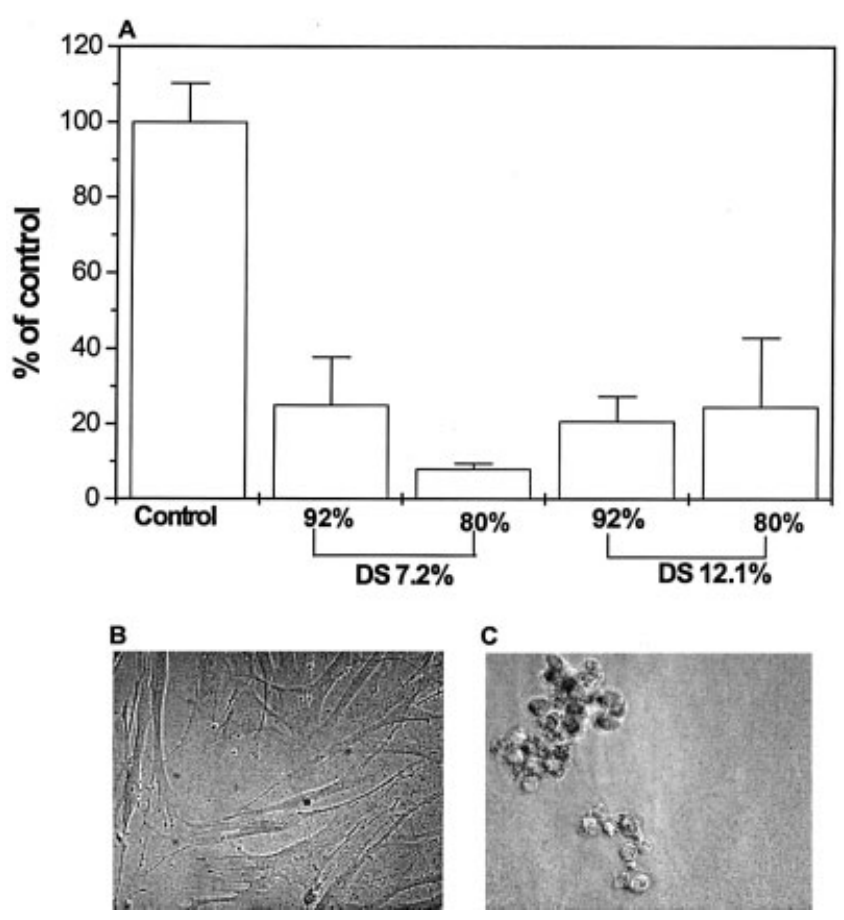

Figure 5. (A) Human skin fibroblasts adhesion (mean \pm $\mathrm{SD}, n=3$ ) into dexT70-VA hydrogels with different DS values and initial water contents. TCPS was used as control. $(\mathrm{B}, \mathrm{C})$ Micrographs from phase-contrast inverted light microscopy of fibroblast adhesion after culturing for $24 \mathrm{~h}$ on TCPS (B) and 80\% dexT70-VA DS $12.1 \%$ hydrogel (C). Original magnification, $200 \times$. 


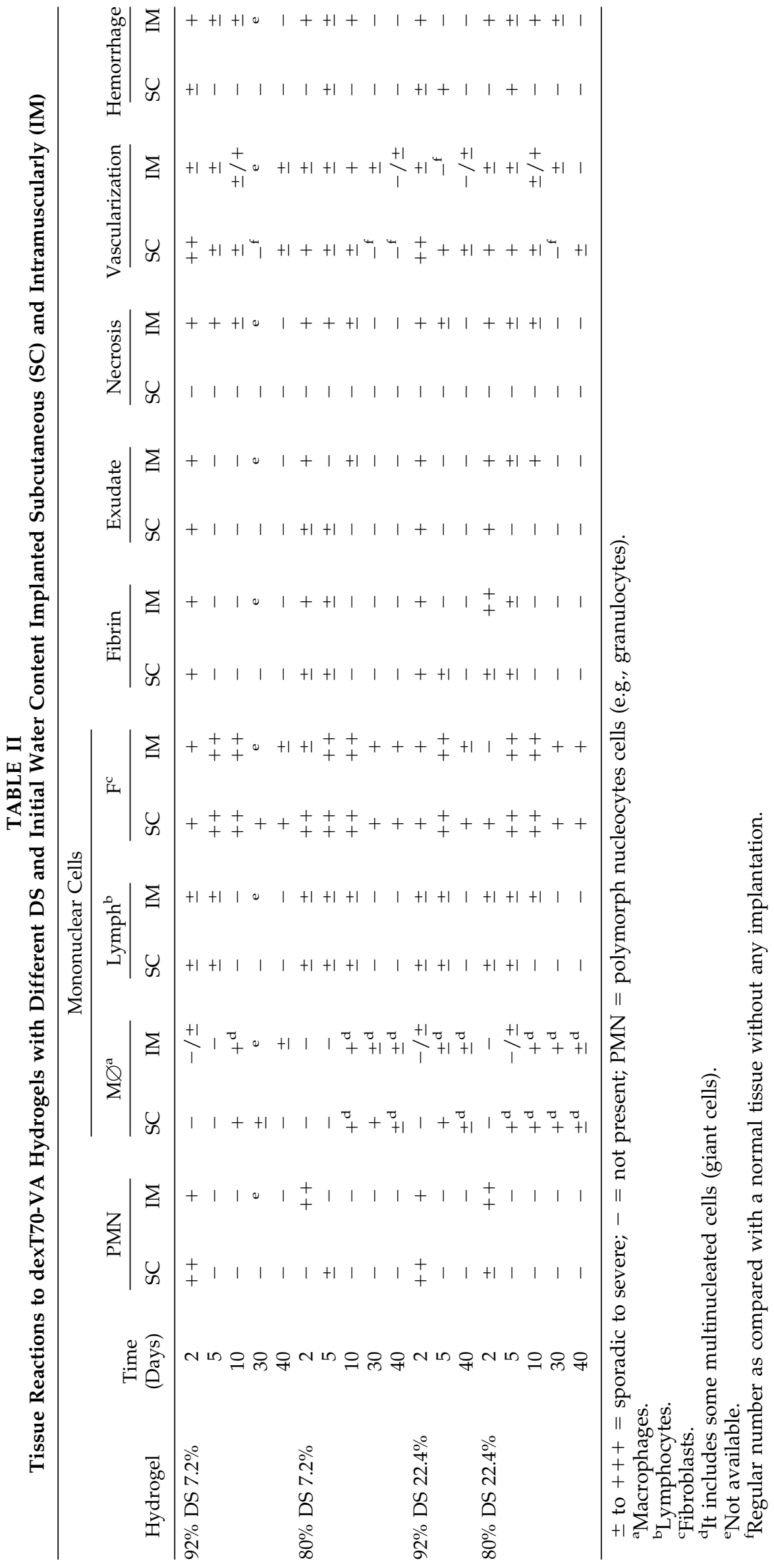


A
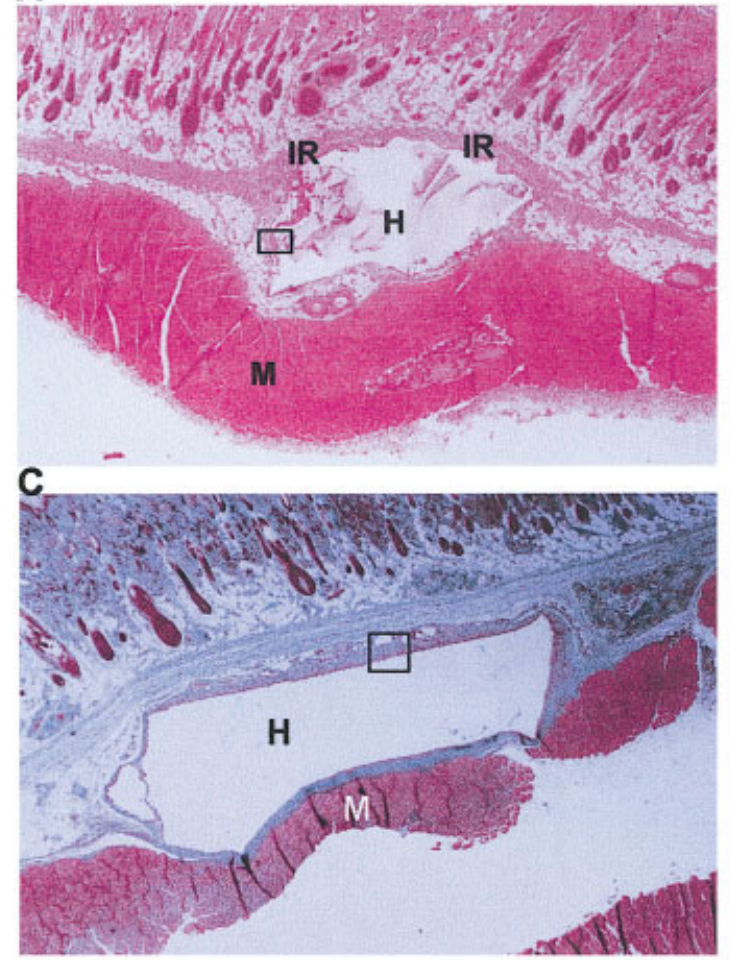

E

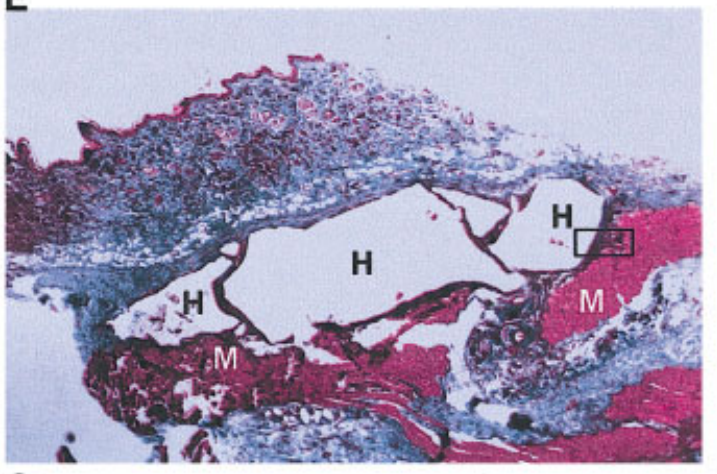

G

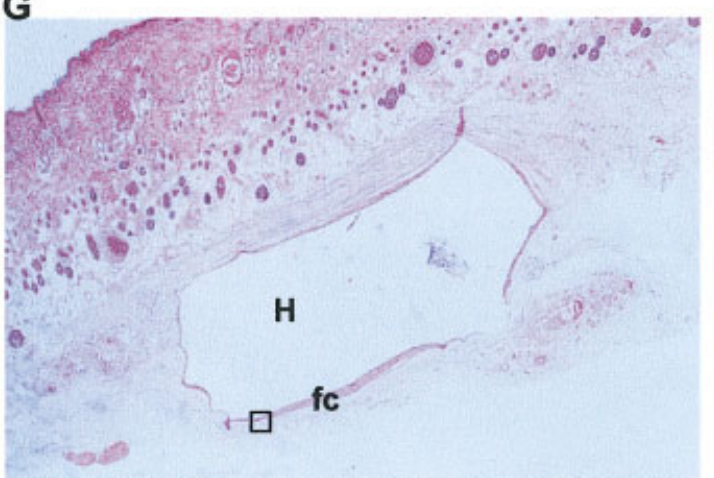

B
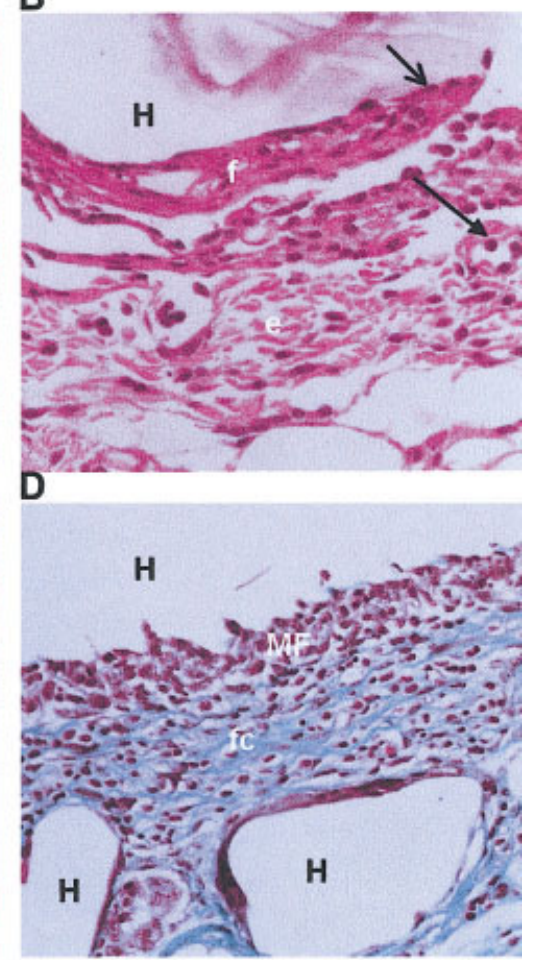

F

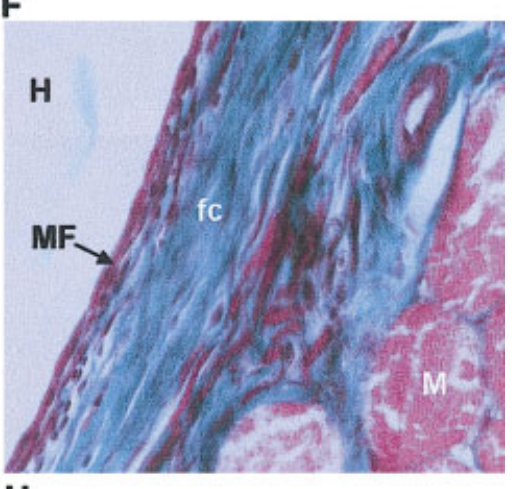

H

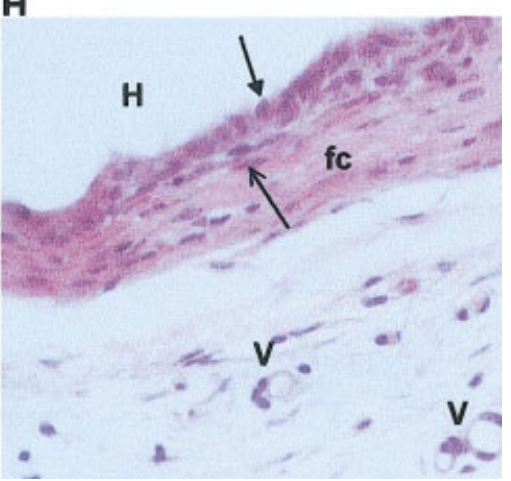

Figure 6. Representative light micrographs of 80\% dexT70-VA DS 7.2\% hydrogel implanted subcutaneously and surrounding tissue (perpendicular slice) at different time points, stained with hematoxylin/eosin (A,B,G,H) and Masson's trichrome $(\mathrm{C}-\mathrm{F})$. Top side is skin; bottom side is underlying muscle $(\mathrm{M})$. (A,B) At day 2, a moderate inflammatory reaction (IR) is seen surrounding the hydrogel $(\mathrm{H})$ : a fibrin layer (f) containing lymphocytes (closed arrow) and fibroblasts (open arrow) is in contact with the hydrogel, whereas some exudate (e) is underlying it. (C,D) At day 10, macrophages and fibroblasts (MF) were surrounding the hydrogel $(\mathrm{H})$ and these were evolved by a starting fibrous capsule (fc). (E,F) At day 30, a moderate foreign-body reaction is seen surrounding the hydrogel $(\mathrm{H})$ : a layer of macrophages and fibroblasts $(\mathrm{MF})$ is seen in the proximity of hydrogel which is surrounded by a fibrous capsule (fc; thickness of ca. $54 \mu \mathrm{m})$. (G,H) At day 40, a minimal foreign-body reaction is surrounding the hydrogel $(\mathrm{H})$ which is identified by a thin fibrous capsule (ca. $35 \mu \mathrm{m})$ with some macrophages (closed arrow) and fibroblasts (open arrow). Some blood vessels (V) are also present in the surrounding tissue. $(\mathrm{A}, \mathrm{C}, \mathrm{E}, \mathrm{G})$ original magnification, $5 \times$; $(\mathrm{B}, \mathrm{F}, \mathrm{H}) 100 \times$; (D) $50 \times$. 
$92 \%$ dexT70-VA DS $7.2 \%$, the fragments were surrounded by a thin discontinuous capsule, whereas on 80\% dexT70-VA DS $22.4 \%$ hydrogel, giant cells were found.

At day $40,80 \%$ dexT70-VA DS $7.2 \%$ hydrogel [Fig. $6(\mathrm{G}, \mathrm{H})]$ was covered by one or two layers of macrophages and fibroblasts including some giant cells. This cell layer was surrounded by a thin fibrous capsule $(35.14 \pm 21.58 \mu \mathrm{m}, n=4)$. Similar tissue reactions were observed for the other dextran hydrogels, except for $92 \%$ dexT70-VA DS $7.2 \%$ hydrogel where the network was highly fragmented and no continuous fibrous capsule was observed. The fragments were surrounded mainly by fibroblasts and no giant cells were observed. Furthermore, the cells appeared to begin to invade the hydrogel.

\section{Intramuscular implantation}

After intramuscular implantation of hydrogels (Table II), the observed tissue reactions were more severe than those described for subcutaneous implantation. At an early stage (day 2), an intense inflammatory process was observed at the implantation site with $80 \%$ dexT70-VA DS 7.2\%. Granulocytes and mononucleated cells infiltrated into muscle tissue, and muscle cell necrosis (as measured by the presence of "ghost cells", i.e., weakly stained cells) was observed. Similar tissue reactions were found for the remaining hydrogels; however, hydrogels with lower water contents $(80 \%)$ showed slightly higher initial tissue response than dextran hydrogels with higher water contents $(92 \%)$, as indicated by the increased infiltration of granulocytes (Table II) into the implantation area. To check whether this response was due to the implant or to the extent or degree of defect created by the implantation procedure, histologic evaluation on rats with unfilled surgical implant was performed. Tissue responses with the same intensity and extent were observed, indicating that the procedure of implantation had a more significant effect on tissue response than the biomaterial itself.

The aforementioned tissue reaction had decreased by day 10 , and granulocytes originally at the implantation site were replaced by mononucleated cells with the start of fibrous capsule observed. At days 30 and 40 , the cellular infiltration of muscle cells was delimited to small areas and the necrosis process ceased. A thin fibrous capsule $(<40 \mu \mathrm{m})$ was observed at days 30 and 40 for all hydrogels tested with the exception of 92\% dexT70-VA DS 7.2\% hydrogel, where a continuous fibrous capsule was not observed even after 40 days. At these implantation times, the hydrogels were surrounded by fibroblasts, macrophages, and some giant cells. Higher numbers of giant cells were ob- served in dextran hydrogels with lower initial water contents $(80 \%)$.

In general, the fragmentation process was large in $92 \%$ dexT70-VA DS 7.2\% hydrogel, reaching in some cases about $80 \%$ of the overall area. This process was minimal with the other hydrogels, normally occurring only at the outer limits of the gel networks. As expected, the hydrogel fragmentation was higher for intramuscular than subcutaneous implantation, presumably because of the mechanical stress promoted by the movement of the animal.

To assess the degradability of hydrogels, the tissue surrounding hydrogels was stained with PAS. ${ }^{14,19}$ All tissue sections (subcutaneous or intramuscular implants) were PAS staining negative, which indicated that cells did not uptake (e.g., by phagocytosis) the hydrogels, during the time frame of this study.

\section{DISCUSSION}

The information obtained from sol-gel fractions is important for biocompatibility assessment, as either unreacted monomers or polymerization initiators may be cytotoxic. Our results show that hydrogels prepared with lower initial water contents in the polymerization reaction had higher gel fractions, and consequently lower sol fractions (i.e., unreacted monomers that can be released from the hydrogel). This is not surprising because the reaction of highly concentrated solutions of dextran acrylate monomers is favored over low concentrated ones. ${ }^{1}$

The likely leachable products from dexT70-VA hydrogels showed different in vitro biocompatibility profiles. Dextran had a minimal effect on cell viability. The only effect was observed at low concentrations (10 $\mathrm{mg} / \mathrm{mL}$ ) and consisted of a slight increase in MMAF. This effect can be attributed to the increase of either cell viability or the mitochondrial succinic dehydrogenase enzyme activity (responsible for MTT metabolism) or possibly both by an unknown mechanism. Regarding cell proliferation, dextran exhibited a relative inhibition of $18-35 \%$ depending on its concentration. Similar CPII values $(25 \pm 7 \%)$ were reported previously ${ }^{13}$ for dextran with a molecular weight of 40 $\mathrm{kDa}(100 \mathrm{mg} / \mathrm{mL})$ using human skin fibroblasts and using similar conditions as used in the current study.

Considering that the sol fraction of hydrogels was less than 22 and $44 \%$ (Table I) for 80 and $92 \%$ dexT70-VA hydrogels, respectively, the maximum amount of dexT70-VA released will be $<43 \mathrm{mg} / \mathrm{mL}$. In this concentration range, dexT70-VA monomer with different DS values slightly decreased (10-20\%) cell viability; however, it exerted a pronounced effect on cell proliferation, which was significantly different from that exhibited by dextran itself. This effect may 
be related to the presence of vinyl groups that may interfere with cell proliferation. Finally, as expected, either APS or TEMED reduced substantially cell viability and dramatically cell proliferation. This effect was expected, because free radicals can react with biological molecules (lipids, proteins, carbohydrates, and nucleic acids) and thus interfere with cell viability and proliferation. ${ }^{21}$

Dextran hydrogels showed good in vitro biocompatibility. Using the extraction assay, dextran hydrogels did not reduce cell viability by more than about $10 \%$ (suggesting that APS and TEMED were not released during extraction), and this effect was only observed with hydrogels prepared with an initial water content of $80 \%$. Interestingly, nonextracted hydrogels with an initial water content of $92 \%$ induced a significant increase in the MMAF. This may be due to the release of small amounts of dextran (or dexT70-VA that is degraded in solution into dextran by hydrolysis of the acrylate ester linkages) from these hydrogels, which increases the MMAF as already demonstrated in hydrogel component cytotoxicity tests. Unexpectedly, the CPII assay (direct contact) results showed that these polymeric networks exerted pronounced cell proliferation inhibition (53-80\%) when compared with the control, and this effect was dependent on the size of hydrogels. Hydrogels with larger diameters presented higher CPII; however, the differences among hydrogels were found to be negligible upon normalizing the CPII as a function of the hydrogel diameter. In addition, differences in cell morphology and number were observed for cells underneath the hydrogels but not in their proximity. This effect may be related to mechanical stress of the hydrogels on the cells or poor $\mathrm{O}_{2} / \mathrm{CO}_{2}$ exchange due to the physical presence of the network. Indeed, the CPII values obtained by the indirect contact assay were $<16 \%$ and not significantly different from the control. Hence, dextran hydrogels only slightly reduced cell viability $(<10 \%)$ and cell proliferation $(<16 \%)$ and, therefore, may be considered as noncytotoxic polymer networks.

The study of dextran hydrogel interaction with fibroblasts showed that the hydrogels were nonadhesive compared with TCPS. This resistance to cell adhesion was presumably due to poor protein adsorption $^{6,7}$ onto the hydrophilic and nonionic dextran. Similar results were obtained by Massia and Stark ${ }^{8}$ in surfaces grafted with dextran, using endothelial and smooth muscle cells, and 3T3 fibroblasts. Moreover, these authors reported cell adhesion values $<26 \%$ for all types of cells, which agrees well with our results. The cell adhesion resistance of dextran hydrogels should not be interpreted as a sign of nonbiocompatibility, because other polymers such as polyethylene glycol have similar properties yet are widely recognized as biocompatible. ${ }^{11}$

Finally, we demonstrated that dextran hydrogels are biocompatible in vivo, as determined through subcutaneous and intramuscular implantation studies in rats. The inflammatory and healing responses of rat tissues were influenced either by the implantation process (subcutaneous versus intramuscular) or the DS values and initial water content of the hydrogels. After subcutaneous implantation of dexT70-VA hydrogels, the hydrogels with higher water contents $(92 \%)$ showed slightly higher inflammatory response, as expressed by a higher number of attached neutrophils, when compared with hydrogels with lower water contents $(80 \%)$. It is well known that the primary role of neutrophils is phagocytosis, and these cells are attracted to the implantation site by several factors, including chemoattraction due to the coating of the foreign body with opsonins. ${ }^{22}$ We speculate that the higher number of neutrophils in the proximity of hydrogels with higher water contents may be attributed to the more open structure of these hydrogels ${ }^{1}$ as compared with lower water content hydrogels, and this would likely promote the entrapment of opsonins. Furthermore, the release of leachable products, due to a higher fragmentation process in these hydrogels (mainly in 92\% dexT70-VA DS 7.2\% hydrogel), may attract a high number of granulocytes.

After 10 days, a normal wound-healing response to subcutaneously implanted hydrogels occurred, which varied according to the properties of the hydrogel. Hydrogels with higher DS values presented a higher number of FBGC than those with lower DS values. FBGC are formed by fusion from macrophages ${ }^{23}$ and that process is dependent on the form, composition, and topography of the implanted surface. ${ }^{15,24}$ In general, rough surfaces induce higher FBGC formation than smooth and flat surfaces. ${ }^{24,25}$ According to light microscopy observations, the surface of dextran hydrogels with higher DS values was rougher than those with lower DS values, and this may explain the higher number of FBGC observed in those hydrogels. Furthermore, the wound-healing response was also characterized by the formation of a fibrous capsule involving the hydrogel, except for $92 \%$ dexT70-VA DS 7.2\% hydrogel. In this case, a higher degree of hydrogel fragmentation affected the formation of a continuous fibrous capsule, and the surrounding cells began to invade the hydrogel. In the other hydrogels, the endstage fibrous capsule formation is a typical response of biocompatible polymers that do not undergo biodegradation or bioresorption. ${ }^{15,16}$ The thickness of the fibrous capsule at day 40 ( $<55 \mu \mathrm{m}$ for all hydrogels) is comparable to ${ }^{26}$ or slightly lower ${ }^{27,28}$ than other biocompatible materials described in the literature when implanted subcutaneously into rats during about 6 weeks. Indeed, this parameter is important in evaluating the performance of implantable drug delivery systems and scaffolds, as thick fibrous capsule may impede the diffusion of therapeutic substances and 
prevent effective implant integration. Along those lines, it has been demonstrated that fibrous capsule thickness of 10-35 $\mu \mathrm{m}$ does not circumvent the release of insulin from poly(hydroxyethyl methacrylate) sponges implanted in rats. ${ }^{29}$ Therefore, it is likely that the capsule thickness values obtained herein would not interfere in therapeutic protein release from hydrogels. Further studies are now underway to demonstrate protein release from implanted dextran-based hydrogels.

The tissue response by intramuscular implantation of hydrogels was more severe than the subcutaneous implantation. The degeneration process during the first $5-10$ days was likely ascribed to surgical trauma ${ }^{30}$ caused by the intramuscular implantation, and this was confirmed by similar tissue reaction in the unfilled surgical implant site control. Therefore, the higher degree of surgical trauma during the first 10 days precludes our ability to clearly interpret the biological response to the hydrogels. However, at days 30 and 40 , the tissue response showed the formation of a thin fibrous capsule $(<40 \mu \mathrm{m})$ for all hydrogels excluding $92 \%$ dexT70-VA DS 7.2\% hydrogel, as well as minor and well-confined infiltration of fibroblasts and macrophages at the muscle tissue, likely due to the movement of the hydrogel relatively to the tissue. Thus, dextran hydrogels present acceptable muscle tissue compatibility. Finally, after about 6 weeks of either subcutaneous or intramuscular implantation, the hydrogels did not show signs of degradation. Hence, the acrylate ester linkages are stable at physiologic $\mathrm{pH}$ and the presence of esterolytic enzymes in tissues. This agrees with previous studies showing the nondegradability of dextran-methacrylate hydrogels ${ }^{14}$ obtained by chemical routes.

In summary, in vitro biocompatibility studies have demonstrated that chemoenzymatically generated dextran-based hydrogels do not significantly promote cell adhesion and minimally impact cell viability and proliferation. These hydrogels, therefore, may be considered noncytotoxic. In vivo studies indicated that all hydrogels elicited a mild inflammatory response after subcutaneous implantation; however, intramuscular implantation resulted in trauma, which partially masked a potential inflammatory response from hydrogel implantation. Nevertheless, the foreign-body reaction was normal for subcutaneous and intramuscular implantation and varied according to the DS value and initial water content of hydrogels. Thus, dextran hydrogels can be considered as biocompatible networks, because the cellular response after implantation was normal, the fibrous capsule surrounding hydrogels had a thickness similar to those of other biocompatible materials, and neither damage nor necrosis of the surrounding tissues of the implant was observed.
The authors thank Miguel Trigo Carvalho for skilled technical assistance.

\section{References}

1. Ferreira L, Gil MH, Dordick JS. Enzymatic synthesis of dextran-containing hydrogels. Biomaterials 2002;23:3957-3967.

2. Peppas NA, Bures P, Leobandung W, Ichikawa H. Hydrogels in pharmaceutical formulations. Eur J Pharm Biopharm 2000; 50:27-46.

3. Park K, Park H. Biocompatibility issues of implantable drug delivery systems. Pharm Res 1996;13(12):1770-1776.

4. Novick SJ, Dordick JS. Preparation of active and stable biocatalytic hydrogels for use in selective transformation. Chem Mater 1998;10(4):955-958.

5. Letourneur D, Machy D, Pellé A, Marcon-Bachari E, Dángelo G, Vogel M, Chaubert F, Michel J-B. Heparin and non-heparinlike dextrans differentially modulate endothelial cell proliferation: In vitro evaluation with soluble and crosslinked polysaccharide matrices. J Biomed Mater Res 2002;60:94-100.

6. Österberg E, Bergström K, Holmberg K, Schuman TP, Riggs JA, Burns NL, Van Alstine JM, Harris JM. Protein-rejecting ability of surface-bound dextran in end-on and side-on configurations: comparison to PEG. J Biomed Mater Res 1995;29:741747.

7. Frazier RA, Matthijs G, Davies MC, Roberts CJ, Schacht E, Tendler SJB. Characterization of protein-resistant dextran monolayers. Biomaterials 2000;21:957-966.

8. Massia SP, Stark J. Immobilized RGD peptides on surfacegrafted dextran promote biospecific cell attachment. J Biomed Mater Res 2001;56:390-399.

9. Wong WH, Mooney DJ. Synthesis and properties of biodegradable polymers used as synthetic matrices for tissue engineering. In: Atala A, Mooney DJ, editors. Synthetic biodegradable polymer scaffolds. Boston, MA: Birkhäuser; 1997. p 50.

10. Lee KY, Mooney DJ. Hydrogels for tissue engineering. Chem Rev 2001;101(7):1869-1879.

11. Hern DL, Hubbell JA. Incorporation of adhesion peptides into nonadhesive hydrogels useful for tissue resurfacing. J Biomed Mater Res 1998;39:266-276.

12. Mann BK, Gobin AS, Tsai AT, Schmedlen RH, West JL. Smooth muscle cell growth in photopolymerized hydrogels with cell adhesive and proteolytically degradable domains: synthetic ECM analogs for tissue engineering. Biomaterials 2001;22:3045-3051.

13. De Groot CJ, Van Luyn MJA, Van Dijk-Wolthuis WNE, Cadée JA, Plantinga JA, Den Otter W, Hennink WE. In vitro biocompatibility of biodegradable dextran-based hydrogels tested with human fibroblasts. Biomaterials 2001;22:1197-1203.

14. Cadée JA, Luyn MJA, Brouwer LA, Plantinga JA, van Wachem PB, Groot CJ, Otter W, Hennink WE. In vivo biocompatibility of dextran-based hydrogels. J Biomed Mater Res 2000;50:397-404.

15. Anderson JM. In vivo biocompatibility of implantable delivery systems and biomaterials. Eur J Pharm Biopharm 1994;40(1): $1-8$.

16. Anderson JM. Inflammation, wound healing, and the foreign body reaction response. In: Ratner BD, Hoffman AS, Schoen FJ, Lemons JE, editors. Biomaterials science. New York: Academic Press; 1996. p 165-173.

17. ISO 10993-5: biological evaluation of medical devices. Test for cytotoxicity: in vitro methods. Geneva, Switzerland: International Organization for Standardization; 1992.

18. Pizzoferato A, Ciapetti G, Stea S, Cenni E, Arciola CR, Granchi D, Savarino L. Cell culture methods for testing biocompatibility. Clin Mater 1994;15:173-190.

19. Bancroft JD, Stevens A. Theory and practice of histological techniques. Edinburg: Churchill Livingstone; 1996. p 99-211. 
20. Mosmann T. Rapid colorimetric assay for cellular growth and survival: application to proliferation and cytotoxicity assays. J Immunol Methods 1983;65:55-63.

21. Moreau MF, Chappard D, Lesourd M, Monthéard JP, Baslé MF. Free radicals and side products released during methylmethacrylate are cytotoxic for osteoblastic cells. J Biomed Mater Res 1998;40:124-131.

22. Black J. The inflammatory response. In: Black J, editor. Biological performance of materials. New York: Marcel Dekker; 1999. p 131.

23. Murch AR, Grounds MD, Marshall CA, Papadimitriou JM. Direct evidence that inflammatory multinucleate giant cells form by fusion. J Pathol 1982;137:177-180.

24. Kuijpers AJ, Wachem PB, Luyn MJA, Plantinga JA, Engbers GHM, Krijgsveld J, Zaat SAJ, Dankert J, Feijen J. In vivo compatibility and degradation of crosslinked gelatin gels incorporated in knitted Dacron. J Biomed Mater Res 2000;51:136-145.

25. Kuijpers AJ, van Wachem PB, Luyn MJA, Brouwer LA, Engbers GHM, Krijgsveld J, Zaat SAJ, Dankert J, Feijen J. In vitro and in vivo evaluation of gelatin-chondroitin sulphate hydrogels for controlled release of antibacterial proteins. Biomaterials 2000;21:1763-1772.
26. Hooper KA, Macon ND, Kohn J. Comparative histological evaluation of new tyrosine-derived polymers and poly(L-lactic acid) as a function of polymer degradation. J Biomed Mater Res 1998;41:443-454.

27. Bos RRM, Rozema FR, Boering G, Nijenhuis AJ, Pennings AJ, Verwey AB, Nieuwenhuis P, Jansen HWB. Degradation of and tissue reaction to biodegradable poly(L-lactide) for use as internal fixation of fractures: a study in rats. Biomaterials 1991; 12:32-36.

28. Nakamura T, Veda H, Tsuda T, Li $Y-H$, Kiyotani T, Inoue M, Matsumoto K, Sekine T, Yu L, Hyon S-H, Shimizu Y. Longterm implantation test and tumorigenicity of polyvinyl alcohol hydrogel plates. J Biomed Mater Res 2001;56:289-296.

29. Dziubla TD, Torjman MC, Joseph JI, Murphy-Tatum M, Lowman AM. Evaluation of porous networks of poly(2-hydroxyethylmethacrylate) as interfacial drug delivery devices. Biomaterials 2001;22:2893-2899.

30. Spector M, Lalor PA. In vivo assessment of tissue compatibility. In: Ratner BD, Hoffman AS, Schoen FJ, Lemons JE, editors. Biomaterials science. New York: Academic Press; 1996. p $220-$ 228. 